\title{
Structure of Bacterial Cellulose-Brightener Complex from Aspect of Behavior of Its Mercerization
}

\author{
Akira KaI and Ping XU \\ Department of Industrial Chemistry, Faculty of Technology, \\ Tokyo Metropolitan University, Fukazawa, Setagaya, \\ Tokyo 158, Japan
}

(Received June 5, 1990)

\begin{abstract}
The structure of the cellulose-brightener complex obtained from the Acetobacter-culture in the presence of a fluorescent brightener was examined from the aspect of mercerization. The cellulose from the culture with the brightener showed characteristic X-ray diffraction indicating the formation of the crystalline complex with the brightener, regardless of the strain cell and brightener concentration of the medium. The brightener content in the complex from the incubated medium with it of below $0.05 \mathrm{wt} \%$ increased with its concentration. In the case of more than $0.05 \mathrm{wt} \%$, the sites of the complex being able to dye were saturated by the brightener. The resistance toward alkali of the never-dried complex decreased with decreasing brightener content, and that of the complex from the incubated medium with the brightener of about $0.005 \mathrm{wt} \%$ became minimum. The resistance toward alkali of the dried complex including the brightener of $0.059 \mathrm{~mol} \mathrm{~mol}^{-1}$ of glucose residue, became higher than that of the never-dried sample. In contrast, that of the dried complex including the brightener of $0.095 \mathrm{~mol}$, became lower than that of the never-dried sample.
\end{abstract}

KEY WORDS Acetobacter xylinum / Fluorescent Brightener / CelluloseBrightener Complex / Brightener Content / Never-Dried Complex / Dried Complex / Cellulose Sheet / Mercerization / Resistance toward Alkali / Cell II content /

Cellulose from the Acetobacter-culture in the presence of a fluorescent brightener, one of the direct dyes for cellulose, does not form a fibril, but a tape. However, this product reforms cellulose I (Cell I) after dye-extraction. Haigler et al. reported that this product is in the noncrystalline state. ${ }^{1} \mathrm{We}$ found that the product from the culture with the brightener is a crystalline complex of cellulose and the brightener. $^{2,3}$ In contrast, Haigler et al. recently refuted from the aspects of electron microscopy of the product obtained from the culture with various direct dye, that the dyes adhered to the surface of a protofibril in a stack. ${ }^{4}$ More recently, we found that products from the culture with a congo red and a direct red 80 showed characteristic $\mathrm{X}$-ray diffraction diagrams indicating the formation of the crystalline complexes, and they reproduced Cell IV and II after dye-extraction, respectively. ${ }^{5}$

Examination of the structure of the product from the Acetobacter-culture in the presence of a direct dye is essential to clarify the mechanism of Cell I formation. In this paper, the structure of the only bacterial cellulose-brightener complex maintaining Cell I formation-ability was examined from the aspect of mercerization.

\section{EXPERIMENTAL}

\section{Material}

Complex Sample: The Acetobacter-culture (Acetobacter xylinum IFO 13693, ATCC 23769) in the presence of the fluorescent brightener $\left(4,4^{\prime}\right.$-bis [2-hydroxyethyl)amino- 
A. KAI and P. XU

Table I. Number of samples

\begin{tabular}{llllll}
\hline Brightener concentration:wt\% & 0 & 0.005 & 0.01 & 0.05 & 0.1 \\
\hline $\begin{array}{l}\text { Complex } \\
\begin{array}{l}\text { Alkali-treated sample of the } \\
\text { never-dried complex }\end{array}\end{array}$ & 0 & 0.005 & 0.01 & 0.05 & 0.1 \\
$\begin{array}{l}\text { Alkali-treated sample of the } \\
\text { dried complex }\end{array}$ & $0 \mathrm{D}$ & $0.005 \mathrm{D}$ & $0.01 \mathrm{D}$ & $0.05 \mathrm{D}$ & $0.1 \mathrm{D}$ \\
\hline
\end{tabular}

1,3,5-triazin-2-yliamino]-2,2'-stilbene disulfonic acid) was performed as described in the previous paper. ${ }^{2,3} 60 \mathrm{ml}$ of cell suspension were added to $140 \mathrm{ml}$ of the complex medium $(\mathrm{pH}$ 7.0) with the brightener of a given concentration (ranging from 0.001 to $0.1 \mathrm{wt} \%$ ), and this was incubated at $28.0^{\circ} \mathrm{C}$ for $24 \mathrm{~h}$. The product was washed thoroughly with $0.2 \mathrm{wt} \%$ aqueous $\mathrm{NaOH}$ solution for $48 \mathrm{~h}$, rinsed with distilled water until alkali-free, and then dried.

Extracted Sample: The never-dried complex was extracted by boiling in a solution of $70 \mathrm{vol} \%$ aqueous ethanol for $18 \mathrm{~h}$ (aqueous ethanol was exchanged for fresh every $3 \mathrm{~h}$ ). The sample was then purified in a boiling $1 \mathrm{wt} \%$ aqueous $\mathrm{NaON}$ solution for $10 \mathrm{~h}$ under an $\mathrm{N}_{2}$ atmosphere.

Alkali-Treated Sample: Alkali-treatment of the never-dried complex: To the incubated medium was added dropwise an equal volume of aqueous $\mathrm{NaOH}$, twice as dense as the given concentration. After gently stirring a homogeneous alkaline solution, it was kept at $20.0^{\circ} \mathrm{C}$ for $1 \mathrm{~h}$. The alkali-treated sample was prepared after dye-extraction as described above.

Alkali-Treatment of the Dried Complex: The complex described as "Complex sample" was treated with $10.4 \%$ aqueous alkali solution for $1 \mathrm{~h}$ at $20.0^{\circ} \mathrm{C}$.

Amorphous Cellulose: Cellulose being soluble in the mixed solvent of dimethyl sulfoxidediethylamine- $\mathrm{SO}_{2}$ was regenerated in water, and dried. (Sample was supplied from Dr. Isogai.)

The samples mentioned above were named as shown in Table I.
Measurement of the Brightener content in the Complex

3-4 mg of the complex weighted exactly were dissolved in a solution of distilled dimethyl sulfoxide, $20 \mathrm{ml}$ and paraformaldehyde, $1 \mathrm{~g}$ under $\mathrm{N}_{2}$ atmosphere for $1 \mathrm{~h}$ at $130^{\circ} \mathrm{C}$. The brightener content in the complex was determined from the visible spectroscopy of the solution. The calibration curve for the measurement of the brightener content was obtained by the visible spectroscopy of the dye solution of the same solvent. This calibration curve was not influenced by cellulose.

\section{$X$-Ray Measurements}

$X$-Ray Diffraction Diagram: $4 \mathrm{mg}$ of the sample were compressed to a $2 \mathrm{~mm} \phi$ diameter, $1 \mathrm{~mm}$ thick isotropic disk. The samples were fixed on the fiber specimen attachment, and their X-ray diagrams were made with Ni filtered $\mathrm{CuK} \alpha$ radiation. The conditions of measurement were as follows: collimator, $1 \mathrm{~mm} \phi$; receiving slit, $0.3 \mathrm{~mm}$; scanning speed, $4.0^{\circ}$ $\min ^{-1}$; X-ray radiation, $40 \mathrm{kV}, 250 \mathrm{~mA}$.

Measurement of Crystallinity: The integrated intensity due to the crystalline component is obtained by subtracting the area of the diffraction curve of an amorphous cellulose from the corresponding area of the sample in the range of $2 \theta=7.5-32.5^{\circ}$, as shown in Fig. 1. The crystallinity of each sample was calculated from the area of the crystalline component and the whole area.

Calculation of Cell II Content in the Alkali-Treated Sample: The Cell II content of the sample was obtained by Rånby's method. ${ }^{6}$ 


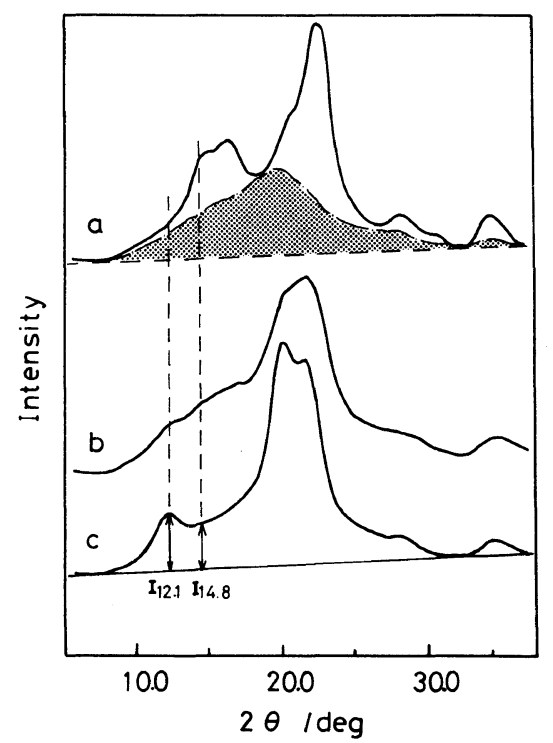

Figure 1. Integrated areas of amorphous cellulose and the sample, and the values of $I_{(12.1)}$ and $I_{(14.8)}$. a, reproduced Cell I (Cell II content, $0 \%$ ); b, sample of Cell II (Cell II content, 60\%); c, reproduced Cell II (Cell II content, $100 \%$ ).

$$
\text { Cell II }(\%)=\left(R_{\mathrm{X}}-R_{\mathrm{I}}\right) \times 100 /\left(R_{\mathrm{II}}-R_{\mathrm{I}}\right)
$$

In this expression, $R_{\mathrm{X}}$ is $2 I_{(12.1)} /\left(2 I_{(12.1)}+\right.$ $\left.I_{(14.8)}\right)$ of the sample. $R_{\mathrm{I}}$ and $R_{\mathrm{II}}$ are $R_{\mathrm{X}}$ of the bacterial cellulose (Cell I) and the mercerized bacterial cellulose (Cell II), respectively. $I_{(12.1)}$ and $I_{(14.8)}$ are the values shown in Figure 1. The integrated intensity of the diffraction curve of each sample in the range of $2 \theta=7.5-32.5^{\circ}$ was standardized to be always constant.

\section{RESULTS AND DISCUSSION}

When $A$. xylinum is cultured, the medium $\mathrm{pH}$ lowers gradually. The brightener is precipitated at $\mathrm{pH}$ 6.6. The medium $\mathrm{pH}$ becomes 6.6 after about $45 \mathrm{~h}$ from the beginning of incubation, although this differs from the metabolism of a bacterium. ${ }^{7}$ Accordingly, the product is obtained from the incubation for $24 \mathrm{~h}$ without the precipitation of the brightener.

All products from the culture with the brightener show the characteristic X-ray

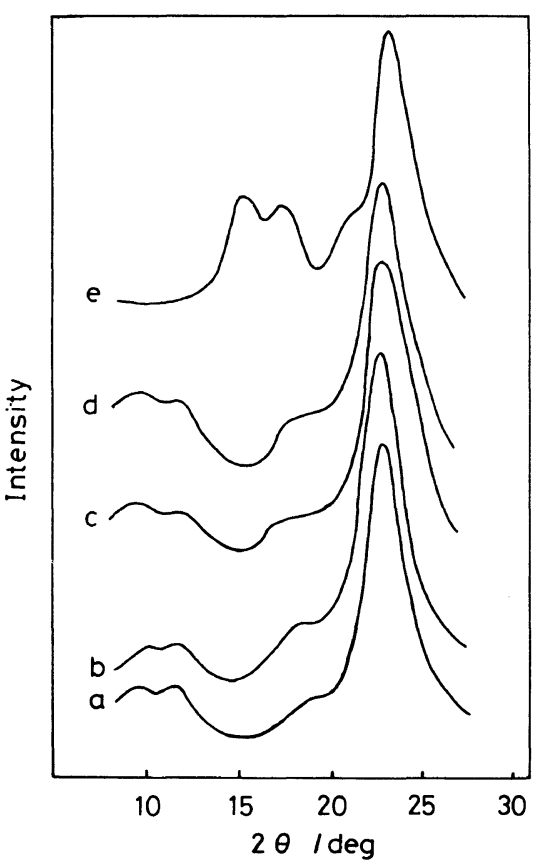

Figure 2. X-Ray diffraction diagrams of the products from the incubated medium with the brightener. Sample No. ATCC 23769: a, 0.1; b, 0.005. Sample No. IFO 13693: c, $0.1 ; \mathrm{d}, 0.005$; e, 0 .

diffraction indicating the crystalline complex of cellulose and the brightener regardless of the strain cell and brightener concentration, as reported by previous paper $^{2,3}$ (Figure 2). In our previous paper, we considered that the sample, after washing with $0.2 \mathrm{wt} \%$ aqueous $\mathrm{NaOH}$ solution and then $70 \mathrm{vol} \%$ aqueous ethanol at room temperature, is still a complex. However, it became clear from this experiment that washing with aqueous ethanol extracts the brightener from the complex. In the case of washing with $0.2 \mathrm{wt} \%$ aqueous $\mathrm{NaOH}$ solution, the X-ray diagram of the complex does not change even after washing for 2 weeks.

The crystallinity of the extracted sample is $45 \%$ (the sample shown in Figure 1a), while that of the conventional bacterial cellulose is $65 \%$. Although the brightener complex does not lose the Cell I formation-ability, the crystallinity of the reproduced Cell I drops.

The brightener content in the complex 


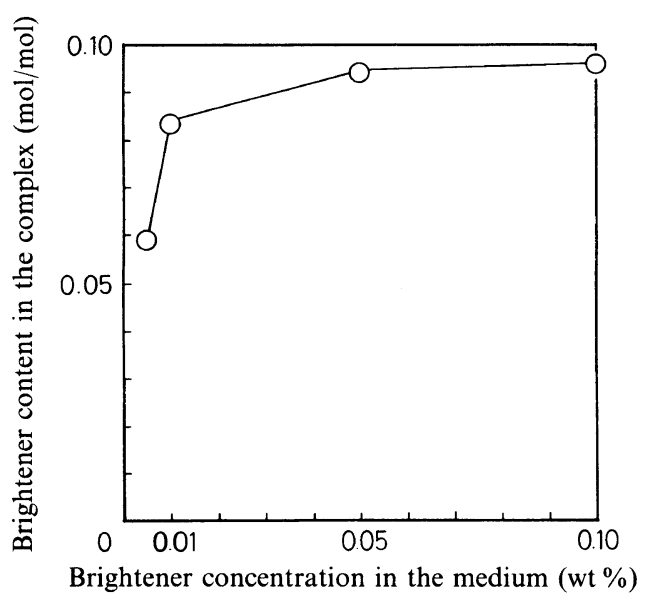

Figure 3. Brightener content in the complex $\left(\mathrm{mol} \mathrm{mol}^{-1}\right.$ of glucose residue). Sample No. 0.1, 0.095; 0.05, 0.095; $0.01,0.083 ; 0.005,0.059$.

produced increases with increasing brightener concentration of the medium, and the values of both 0.05 and 0.1 samples are $0.095 \mathrm{~mol}$ per mol of glucose residue, as shown in Figure 3.

The monolayer of the brightener is included between the cellulose sheets corresponding to the (110) plane of the complex. ${ }^{2}$ The cross-section of a microfibril of bacterial cellulose is about $40 \times 40 \AA^{2}{ }^{8,9}$ This assumes that the surfaces of the microfibril correspond to the $(1 \overline{1} 0)$ and the (110) planes. Since the space of the $(1 \overline{1} 0)$ and the (110) plane is $6.1 \AA$ and $5.4 \AA$, respectively, the microfibril is organized of about seven leaves of a cellulose sheet composing about eight chains. On the other hand, the brightener molecule length is $30.4 \AA$ and, $13.4 \AA$ and thickness, 4-5 $\AA$. When the site of the $(1 \overline{1} 0)$ plane being able to dye and the surface of the complex are saturated by the brightener, 32 molecules are included in the cross-section. Since the molecular length of a brightener is equal to the glucose residue length of six, the brightener content is $0.095 \mathrm{~mol}$ per $1 \mathrm{~mol}$ of the glucose residue. Accordingly, in 0.05 and 0.1 samples, their sites being able to dye must be saturated by the brightener. In contrast to these samples, the sites in the complex of the lower brightener content must be partially occupied by the

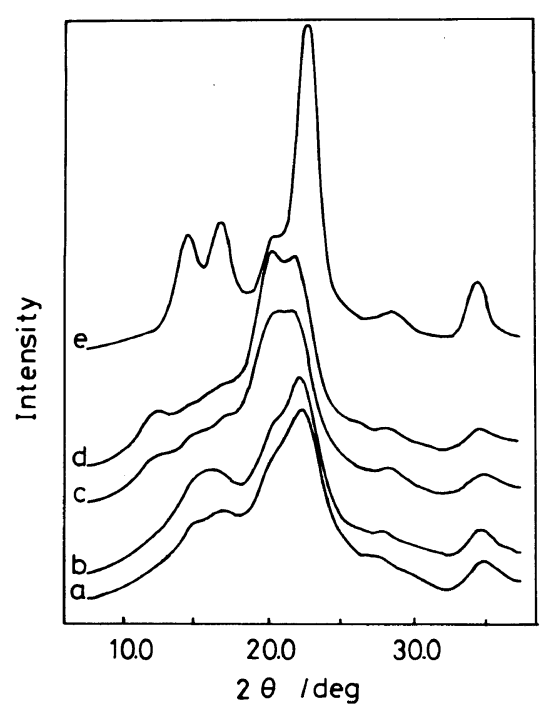

Figure 4. X-Ray diffraction diagrams of the never-dried complexes after alkali-treatment with $10.4 \%$ aqueous $\mathrm{NaOH}$ for $1 \mathrm{~h}$ at $20.0^{\circ} \mathrm{C}$. Sample No. a, 0.1 ND; b, $0.05 \mathrm{ND}$; c, $0.01 \mathrm{ND}$; d, 0.005 ND; e, 0 ND.

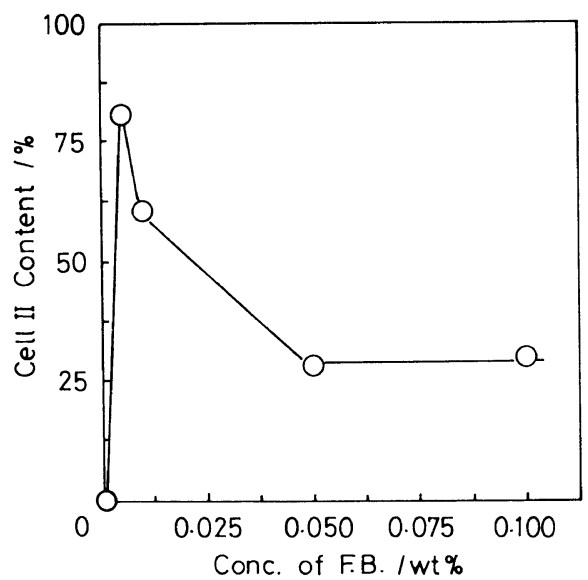

Figure 5. Cell II content in the alkali-treated samples shown in Figure 4.

brightener.

The X-ray diffraction diagrams of the never-dried complexes after the alkali-treatment with $10.4 \mathrm{wt} \%$ aqueous $\mathrm{NaOH}$ solution are shown in Figure 4. Their Cell II contents are shown in Figure 5.

The structure of 0 ND sample is not changed by alkali-treatment of $10.4 \% \mathrm{NaOH}$ solution. As compared with 0 ND sample, the resistance 
toward alkali of both $0.05 \mathrm{ND}$ and $0.1 \mathrm{ND}$ samples is reduced, and Cell II yields about $30 \%$ in both samples. However, their resistance toward alkali is higher than those of $0.01 \mathrm{ND}$ and $0.005 \mathrm{ND}$ samples. The Cell II content of the alkali-treated sample increases with drop in the brightener content. The Cell II contents of $0.01 \mathrm{ND}$ and $0.005 \mathrm{ND}$ samples are 61 and $81 \%$, respectively.

The brightener becomes insoluble in aqueous alkaline solution of more than a few percent. As a result, the brightener included in the complex may behave as a cross-linking agent for the cellulose sheets. Therefore, the resistance toward alkali of $0.1 \mathrm{ND}$ and $0.05 \mathrm{ND}$ samples must be higher than those of the other samples. In the case of the lower brightener content samples, judging from the decline in their resistance, it is suggested that a number of the cross-linking points between cellulose sheets by brightener decreases, and that the brightener continues to prevent mutual bonding of sheets in the wet state. As a result, it is suggested that the invasion of alkali into the complex of the lower brightener content is easy as compared with that of the higher content.

The structure of $0.005 \mathrm{ND}$ sample with the minimum alkali resistance is changed with even $4.3 \%$ or $5 \%$ alkali-treatment during the course of soak time, as shown in Figures 6 and 7.

In case of $5 \%$ alkali-treatment, Cell II of this sample is $0 \%$ for $1 \mathrm{~h}, 78 \%$ for 60 days, and becomes $90 \%$ for 180 days. Even with $4.3 \%$ alkali-treatment, Cell II content becomes $56 \%$ for 180 days. However, the structure of this sample never changes with $3.0 \%$ alkalitreatment. These results support the suggestion above that the invasion of alkali into the samples of the lower brightener content becomes easy. The structure of conventional bacterial cellulose, of course, never changes with $5 \%$ alkali-treatment, even for 210 days.

It is reported that the cellulose sheet corresponding to the $(1 \overline{1} 0)$ plane of Cell I originally maintains the structure in even about $20 \%$ aqueous alkali solution. ${ }^{10}$ The reason is

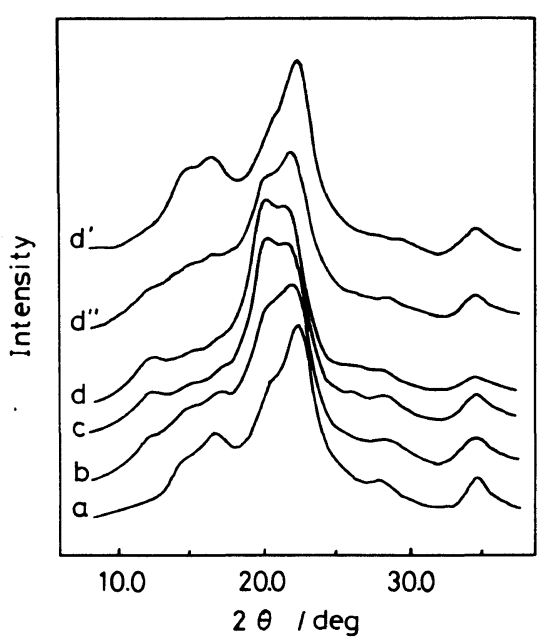

Figure 6. X-Ray diffraction diagrams of the $0.005 \mathrm{ND}$ samples treated with $3.0,4.3$, and $5.0 \mathrm{wt} \%$ aqueous $\mathrm{NaOH}$ for various time at $20.0^{\circ} \mathrm{C}$. Samples No. $5.0 \%$ : a, $1 \mathrm{~h}$; b, 30 days; c, 70 days; d, 180 days. Sample No. $4.3 \%$ : d", 180 days. Sample No. $3.0 \%$ : d', 180 days.

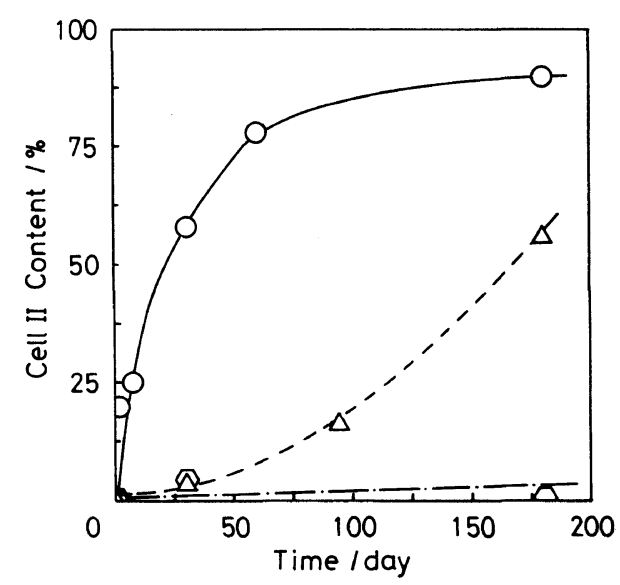

Figure 7. Cell II content in the alkali-treated samples shown in Fig. $6.0,5.0 \% ; \triangle, 4.3 \% ; \bigcirc, 3.0 \%$.

said to be due to intermolecular hydrogen bonding in a sheet. That the change in the structure of the 0.005 ND sample appears even in $5 \%$ aqueous alkali solution suggests that the brightener included in the complex puts into disorder the structure of the sheets, and as a result decreases the intermolecular interaction.

The results on the $10.4 \%$ alkali-treatment of the dried complexes are very interesting, as 


\section{A. KAI and P. XU}

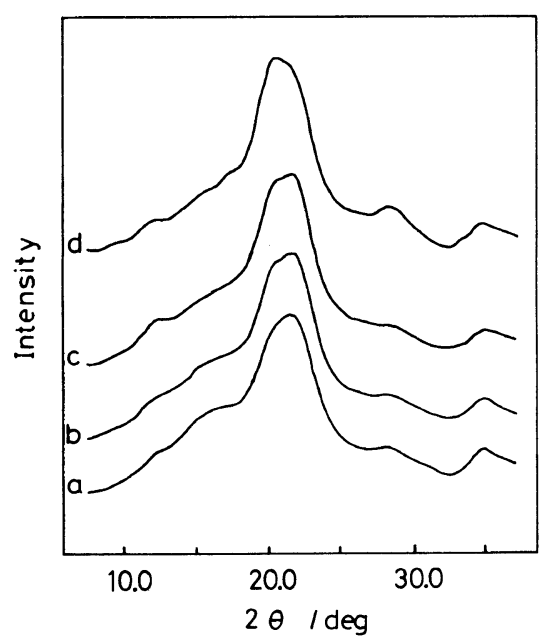

Figure 8. X-Ray diffraction diagrams of the complexes treated with $10.4 \mathrm{wt} \%$ aqueous $\mathrm{NaOH}$ solution for $1 \mathrm{~h}$ at $20.0^{\circ}$ C. Sample NO. a, $0.1 \mathrm{D} ; \mathrm{b}, 0.05 \mathrm{D} ; \mathrm{c}, 0.01 \mathrm{D}$; d, $0.005 \mathrm{D}$.

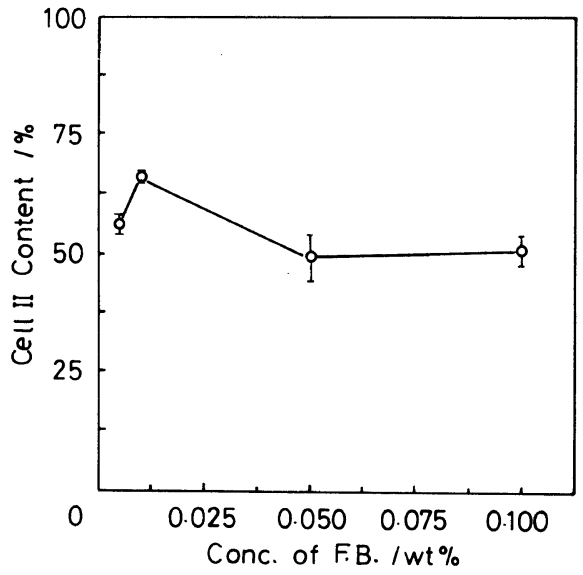

Figure 9. Cell II content in the alkali-treated samples shown in Figure 8.

shown in Figures 8 and 9. The Cell II content of $0.005 \mathrm{D}$ sample is $54 \%$. This value is about $30 \%$ lower than that of 0.005 ND treated with the same condition. The Cell II content of $0.01 \mathrm{D}$ sample is $65 \%$, and almost the same as that of 0.01 ND. However, the Cell II contents of both $0.05 \mathrm{D}$ and $0.1 \mathrm{D}$ samples become about $50 \%$. This value is about $20 \%$ more than those of $0.05 \mathrm{ND}$ and $0.1 \mathrm{ND}$ samples.

These results suggest the following: First, in the case of 0.1 and 0.05 samples being saturated by the brightener, it included between the sheets enlarges the disordering of the structure of the sheets by drying of the complex. In the presence of water the strain of the sheets in the complex must be relaxed due to the plastic effect of water. Secondly, in the case of 0.005 samples whose sites being able to dye must be dotted with the brightener, it is suggested that the direct bonding between the sheets occurs by the drying of the complex, and as a result, its resistance toward alkali increases.

The characteristic behavior of mercerization of the complex firmly supports our conclusion in the previous paper ${ }^{2,3}$ that the product from the culture in the presence of the brightener has the structure including the brightener between the $(1 \overline{1} 0)$ planes. If the brightener adheres to the surface of a protofibril in a stack as Haigler et al. proposed, the behavior of mercerization of all products must be almost independent of the brightener content.

Haigler et al. prepared the samples by washing the product with aqueous $\mathrm{HCl}$ solution of $\mathrm{pH} 3$. As mentioned above, the brightener precipitates at $\mathrm{pH}$ 6.6. In the case of washing the product with aqueous solution of $\mathrm{pH} \mathrm{3,} \mathrm{the} \mathrm{microcrystals} \mathrm{of} \mathrm{the} \mathrm{brightener}$ must grow. In the X-ray diffraction diagram of the sample prepared by washing with

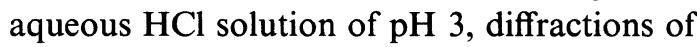
the brightener crystals were observed. When this sample was washed with $0.2 \%$ aqueous $\mathrm{NaOH}$ solution, the diffractions of the brightener crystals disappeared and only those of cellulose appeared. ${ }^{11}$

Acknowledgments. The authors express their appreciation to Dr. A. Isogai, Tokyo University for supplying the amorphous cellulose sample, and Miss S. Ishikita for her technical assistance in the X-ray experiments.

\section{REFERENCES}

1. C. H. Haigler, R. M. Brown, and M. Benziman, 
Science, 210, 903 (1980).

2. A. Kai, Makromol. Chem. Rapid Commun., 5, 307, 653 (1984).

3. A. Kai and H. Kitamura, Bull. Chem. Soc. Jpn., 58, 2860 (1985).

4. C. H. Haigler and H. Chanzy, J. Ultrastruct. Mol. Struct. Res., 98, 299 (1988).

5. A. Kai, Y. Kido, and N. Ishida, Chem. Lett., 949 (1990).

6. B. G. Rånby, Acta Chem. Scand., 6, 116 (1952).

7. A. Kai, P. Xu, S. Ishikita, and N. Ishida, "Proceeding of 4th Cellucon Conference," in press (1989).

8. A. Kai and J. Kogusuri, Nippon Kagaku Kaishi, 536 (1982).

9. R. M. Brown, J. H. M. Willison, and C. L. Richardson, Proc. Natl. Acad. Sci. U.S.A., 73, 4565 (1976).

10. J. O. Warwicker and A. C. Wright, J. Appl. Polym. Sci., 11, 659 (1967).

11. S. Ishikita, P. Xu, and A. Kai, Abstracts of Papers, Part II, 90th Annual Spring Meeting of the Chemical Society of Japan, 1990, p 1074. 